\title{
Understanding Race as a Relational Concept
}

\author{
Natalia Molina
}

In November 2016, just a few days after the presidential election, Carl Higbie, a spokesman for a super PAC that supported Donald Trump, told Fox News host Megyn Kelly that the new Trump administration was considering a national registry for Muslims in the United States. Higbie argued that the proposal was legal and would "hold constitutional muster," and went on to point out that there was precedent for singling out groups based on their race and religion: "We did it during World War II with the Japanese ..." Kelly interrupted him, exclaiming, "You're not proposing we go back to the days of internment camps, I hope!" Though Higbie said he was not proposing internment camps, he continued to insist that that episode from American history was an important precedent for the President-elect's proposal. Kelly was having none of it. "You can't be citing Japanese internment camps for anything the president-elect is going to do," she balked. ${ }^{1}$

Legally, however, Kelly was only partially correct. In February of 1942, President Franklin Roosevelt signed Executive Order 9066, under which approximately 100,000 Japanese and Japanese Americans were sent to internment camps in the U.S. interior. Fred Korematsu, a Japanese American, defied the evacuation orders on the premise that he was a U.S. citizen. He was arrested and convicted for denying the orders and his case, Korematsu v. United States, went to the Supreme Court-which ruled that internment was constitutional and justified in a national security crisis. Since then, many have decried this decision. As early as 1961, Time magazine described internment as "an ugly footnote in American history." Subsequent Supreme Court justices have described the decision as "wrong" (Justice Antonin Scalia); "thoroughly discredited" (Justice Stephen Breyer); and one that "will never again survive scrutiny" (Justice Ruth Bader Ginsburg). But here's the rub: the ruling still stands. It has never been overturned. One can muster all the moral indignation one likes, but in the end, the ruling is still available for people to use as a precedent. $^{2}$

The fact that Japanese internment still serves as a precedent for a national Muslim registry highlights what's at stake in thinking about race as a relational concept. Justice Robert H. Jackson, who wrote a dissent in Korematsu and would later serve as the lead prosecutor in the Nuremberg trials, wrote that the decision was a "loaded weapon, ready for the hand of any authority that can bring forward a plausible claim of an urgent need." This statement is at its heart relational, recognizing the ways in which Japanese internment and later the Korematsu case widened the possibilities for mistreatment of other racialized groups. Here, by relational, I do not mean comparative. A comparative treatment of race compares and contrasts groups, treating them as independent of one another. It also can leave the construction of the categories themselves unexamined, thus reifying them, even if unintentionally. A relational treatment of race, however, recognizes it as a mutually constitutive and socially constructed

\footnotetext{
${ }^{1}$ Lily Rothman, "Why Citing the Japanese Internment as a 'Precedent' for a Muslim Registry Is So Alarming," Time, November 17, 2016, http://time.com/4574680/muslim-registry-japanese-internment/ (accessed Dec. 12, 2017).

${ }^{2}$ Matt Ford, “The Return of Korematsu," Atlantic, November 19, 2015, https://www.theatlantic.com/politics/archive/ 2015/11/the-shadow-of-korematsu/416634/ (accessed Dec. 12, 2017). Most coverage of the national Muslim registry overlooked that the United States already had one in place for a time, the National Security Entry-Exit Registration System (NSEERS), which was enacted shortly after 9/11 and disproportionately targeted Muslims and Arabs.

(c) The Author(s) 2018. Published by Cambridge University Press
} 
process; doing so counteracts essentialist notions of race. Furthermore, it attends to how, when, where, and to what extent groups intersect, pushing against the tendency to examine racialized groups in isolation, which limits our understanding.

My work is dedicated to uncovering the connections among racialized groups. (I use the term "racialized group" vs. race or ethnicity to emphasize that race is a socially constructed category.) My book, How Race Is Made in America: Immigration, Citizenship, and the Historical Power of Racial Scripts, explores how race works relationally through the operation of what I call racial scripts. Racial scripts highlight the ways in which the lives of racialized groups affect each other across time and space, even when they do not directly cross paths. For example, in the 1930s, birthright citizenship was far from an uncontested right for Mexicans. Proposed legislation to limit it during the Depression was fueled not only by economic arguments for stemming the flow of Mexican immigration (arguments that resulted in the repatriation and deportation of nearly one million Mexicans), but also by a longer history of contestations over birthright citizenship for African Americans and Chinese immigrants dating back to the Dred Scott case (1857) and United States v. Wong Kim Ark (1898). The Scott ruling denied full birthright privileges to free blacks born in the United States. The Wong Kim Ark decision eventually did grant birthright citizenship to Asians, but the case established the idea that many still thought Chinese Americans were citizens only by "accident of birth," as stated by Henry S. Foote, the U.S. attorney who argued the case on behalf of the government. The debates about birthright citizenship in the 1930s demonstrate that the same racial scripts that once denied African Americans and attempted to deny citizenship to Chinese Americans made birthright citizenship for those of Mexican descent born in the United States anything but a sure thing. ${ }^{3}$

Racial scripts operate in three main ways. First, they highlight how racialized groups are acted upon by a range of principals, from institutional actors like judges, law enforcement, or public health officials, to ordinary citizens like employers, co-workers, and neighbors. Second, while all groups are racialized, we often do not recognize this shared process, and thus we fail to see their common connections. Examining racial scripts pulls the lens back so that we can see different moments of race-making operating at the same time, affecting different groups simultaneously. Of course, these scripts cannot be automatically transferred from one situation to the next or from one group to another. We must always take into consideration the conditions under which racial scripts emerge-the social structure, the material conditions, and the historical context-and bear in mind that there is no uniform experience of racialization; it varies according to factors like national origins, immigrant status, skin color, language acquisition, and perception of foreignness. Third, racialized groups put forth their own scripts-counterscripts that offer alternatives or directly challenge dominant racial scripts. Just as racial scripts have a seeming pervasiveness, resistance, too, has a long fetch. The process of racialization in general can be more important than the particular identity of the person experiencing it, and seemingly unlikely antiracist alliances can form when groups recognize a resemblance between others' collective experiences of racialization and their own. Thus, counterscripts do not necessarily have to function at the level of high-profile actions, such as protests or community organizing, but can be encompassed in daily expressions of compassion and solidarity. A theory of counterscripts allows us to see how these practices of resistance, claims for dignity, and downright refusal to take it anymore cut across a range of communities of color, thus once again showing us how those communities are linked.

Of course, there is also sometimes a dark side to racial counterscripts. In order to gain civil rights, groups may sometimes argue they are on the right side of the color line rather than

\footnotetext{
${ }^{3}$ Natalia Molina, How Race Is Made in America: Immigration, Citizenship, and the Historical Power of Racial Scripts (Berkeley, CA, 2014).
} 
challenge the color line itself. For example, until the 1952 passage of the McCarran-Walter Act, which permitted Asians and other non-white immigrants to become naturalized citizens, applicants for naturalization had to declare themselves either white or black. Legal scholar Ian Haney-López has documented fifty-two racial prerequisite cases between 1878 and 1952 in which the petitioner had to establish his or her racial eligibility for citizenship. Of these, only one involved an individual who argued that he was black and hence eligible for citizenship. The other fifty-one plaintiffs sued to be declared legally white. ${ }^{4}$ Perhaps the applicants knew that citizenship without whiteness was hollow. Historian George Lipsitz has pointed out that, while whiteness may be a created identity, it has real consequences for the distribution of wealth, prestige, and opportunity. To identify with whiteness, as such, "is to remain true to an identity that provides [people] with resources, power, and opportunity." In these cases, relationality worked to heighten divisions and hierarchies among nonwhites rather than soften them.

But in all cases, racial scripts cannot ever be dismissed as incidental footnotes to history: They are built into institutional structures and practices that form society's "scaffolding," like laws and policies. The history of Chinese exclusion from the late nineteenth century into the twentieth century, for example, did not affect only the Chinese. In her book, At America's Gates, Erika Lee demonstrates that the precedent set by Chinese exclusion laws starting in 1882 set the United States on the path to be a "gatekeeping nation," from which immigrants from all over the world might also be excluded on the basis of race and class (or religion or political beliefs), or put on quotas, or subjected to intrusive medical exams, or denied entry because officials assumed they would become "public charges"-all practices that we still see today. ${ }^{6}$ Thus, rather than Chinese exclusion being some sort of footnote to history or a dark period that has since been rectified, we see that the structures put in place to discriminate against racialized groups were then available to discriminate against other groups. We hail the end of Chinese exclusion in 1943, but we do not often connect how the racial script of Chinese exclusion may have affected the Japanese in the Korematsu ruling in 1944, which reaffirmed the United States' right to discriminate based on race, in this case, in times of a national security crisis.

Racial scripts also endure as cultural representations that shape how we see, experience, and imagine race, as well as its discursive element. Cultural representations may or may not rely on stereotypes, but even when they do not, representations often still rely on certain assumptions, conscious or unconscious-some of which have become so commonplace that we think of them simply as "common sense." Kelly Lytle Hernández vividly demonstrates the creation of negative representations of ethnic Mexicans in Migra! A History of the U.S. Border Patrol. She argues that far from creating a system of impartial law enforcement, the Border Patrol instead used race as an organizing principle in their work, with the result being that they conflated crime and illegality with ethnic Mexicans. ${ }^{7}$ This cultural representation would stigmatize ethnic Mexicans long after their interactions with the border patrol, following them as they settled into their new lives in the United States, and affecting their American citizen children for generations to come. If the idea that ethnic Mexicans are unworthy and hence excludable or deportable endures, then it can be applied to other groups as well. Once attitudes, practices, customs, policies, and laws are directed at one group, they are more readily available and easily applied to other groups. No matter how discredited a given racial script becomes in any era, it is

\footnotetext{
${ }^{4}$ Ian Haney-López, White by Law: The Legal Construction of Race (New York, 1996), 46.

${ }^{5}$ George Lipsitz, The Possessive Investment in Whiteness: How White People Profit from Identity Politics (Philadelphia, 1998), vii.

${ }^{6}$ Erika Lee, At America's Gates: Chinese Immigration During the Exclusion Era, 1882-1943 (Chapel Hill, NC, 2003).

${ }^{7}$ Kelly Lytle Hernández, Migra! A History of the U.S. Border Patrol (Berkeley, 2010).
} 
always available for reuse in new rounds of dehumanization and demonization in the next debate or even the next generation.

Racial scripts can also be used in the classroom. My own training as a twentieth century U.S. historian with a specialization in Latina/o and Chicana/o history involved studying Chicana/o studies, Asian American studies, African American studies, and Native American studies separately. But because I am interested in the visible and hidden connections between groups, I strive to demonstrate how the racial construction of one group affects others, sometimes simultaneously and sometimes at a much later date.

In a typical Chicana/o history survey course, for example, students might examine major timeline events that demonstrate the complex ways in which legal, social, and cultural understandings of race shaped the category "Mexican," such as the 1848 Treaty of Guadalupe Hidalgo that legally classified Mexicans as white and made Mexicans living in lands ceded to the United States eligible for U.S. citizenship. This provision stood unchallenged until 1897, when a man named Ricardo Rodríguez went before the Texas federal district court to have his application for citizenship approved. At issue was whether Rodríguez should be classified as white or black, the criterion at the time for citizenship. The case, In Re Ricardo Rodríguez, was a major civil rights victory, for had Rodríguez been ruled nonwhite and hence ineligible for citizenship, it would have stripped the voting rights of all naturalized Mexicans-not just recent immigrants but many who had lived in the region for decades. Thirty years later, Mexicans' racial and citizenship status was once again at issue, when they were scapegoated for U.S. financial woes in the Depression. In response, the U.S. government not only deported hundreds of thousands of Mexicans, and even some Mexican Americans, but the U.S. census decided to list "Mexican" as a separate race.

I agree with scholars who claim that the years between 1848 and 1930 were pivotal in shaping the meaning of "Mexican" legally, socially, and culturally. But I also argue that we need to understand how such meanings were formed in relation to other devalued and marginalized groups: blacks, Native Americans, and Asians, as well as whites. Thus, I put these events into conversation with Asian American and Native American history. I demonstrate how the moments of race making just described were also influenced by what was going on with other groups. I look at how Mexicans were racialized in relation to Asians; although efforts to deny Mexicans U.S. citizenship failed in 1897, these efforts were renewed after two Supreme Court decisions, Ozawa v. United States (1922) and United States v. Bhagat Singh Thind (1923), declared Japanese and Asian Indians ineligible for citizenship because they were not considered white. White supremacists saw the Ozawa and Thind rulings as an opportunity to nullify Mexicans' claim to U.S. citizenship as well, insisting these landmark citizenship decisions made previous racial designations of Mexicans null and void. In a word, they hoped to apply the racial scripts designed for East Asians and South Asians to Mexicans. Their ultimate aim was, of course, to shore up the definitional walls between "white" and "non-white" population groups, thereby putting even sharper teeth into the severe restrictions on the immigration and naturalization of racially proscribed peoples.

By looking at how ethnic and national groups entered the racial lexicon of the United States during the same period, one begins to see the relationships in racial thinking and the interconnectedness between different categories. It is only by seeing race relationally that we better understand why and how Mexicans were de facto categorized as white in 1848 (as citizenship was only extended to whites at this time) but as a separate race in 1930 .

Put together, these various experiences highlight the complex processes by which race was made in U.S. history. Understanding the relational nature of race and exposing the links sustained by the use of racial scripts brings us one step closer to denaturalizing these scripts and, in the process, challenging the dominant narratives and power structures they support. A better understanding of the relational nature of race also provides groups a 
framework and common ground for recognizing the ways in which their histories, and their futures, are linked.

Natalia Molina's work lies at the intersections of race, gender, culture, and citizenship. She is the author of two award winning books, Fit to be Citizens? Public Health and Race in Los Angeles, 1879-1939 and How Race Is Made in America: Immigration, Citizenship, and the Historical Power of Racial Scripts. With the support of a National Endowment for the Humanities Public Scholar Fellowship, she is expanding her article, "The Importance of Place and Place-makers in the Life of a Los Angeles Community: What Gentrification Erases from Echo Park" into a book. She is also co-editing a volume entitled Studying Race Relationally. She is a Professor of History at University of California, San Diego. 